\title{
FAKTOR INTERNAL DAN EKSTERNAL YANG MEMENGARUHI UNDERPRICING PADA SAAT IPO DI BURSA EFEK INDONESIA
}

\section{THE INTERNAL AND EXTERNAL FACTORS INFLUENCING THE UNDERPRICING OF IPO IN THE INDONESIAN STOCK EXCHANGE}

\author{
Kemas Nurcholish Thoriq ${ }^{*}$, , Sri Hartoyo ${ }^{* *}$, dan Hendro Sasongko***) \\ *) Sekolah Bisnis, Institut Pertanian Bogor \\ Jl. Raya Pajajaran, Bogor 16151 \\ ${ }^{* *}$ Departemen Ilmu Ekonomi, Fakultas Ekonomi dan Manajemen, Institut Pertanian Bogor \\ Jl. Agatis Kampus IPB, Darmaga 16680 \\ ${ }^{* * *}$ Fakultas Ekonomi, Universitas Pakuan \\ Jl. Pakuan PO Box 452, Bogor 16143
}

\begin{abstract}
This study aims to examine the variables that influenced the underpricing stock price when the company put its initial public offering in Indonesia Stock Exchange of the 2010-2015 period. The dependent variable in this study was underpricing measured by the value of initial returns, while the independent variables included ROA, DER, company age, company size, type of Industry, underwriter's reputation, exchange rate and inflation. The data used in this study were secondary data collected by using purposive sampling method. The samples of 135 companies from were taken from 137 population companies conducted IPOs from 2010-2015 in Indonesia Stock Exchange. This study used logistic regression for data analysis. The results of this study showed that ROA, DER, age and inflation influenced the level of underpricing is proven. Other variables influencing the level of underpricing is not proven. This research model showed that the independent variables explained the variation in the level of underpricing of $89.6 \%$.
\end{abstract}

Keywords: underpricing, internal and external factors, ROA, DER

\begin{abstract}
Abstrak: Penelitian ini bertujuan untuk menganalisis variabel-variabel yang memengaruhi underpricing harga saham perusahaan saat penawaran umum perdana di Bursa Efek Indonesia periode 2010-2015. Variabel dependen pada penelitian ini adalah underpricing yang diukur menggunkan nilai initial return, sedangkan variabel independennya adalah ROA, DER, umur perusahaan, ukuran perusahaan, jenis industri, reputasi underwriter, nilai tukar rupiah dan inflasi. Data yang digunakan dalam penelitian ini adalah data sekunder yang dikumpulkan menggunakan metode purposive sampling. Sampel perusahaan sebanyak 135 perusahaan dari populasi 137 perusahaan yang melakukan IPO dari tahun 2010-2015 di Bursa Efek Indonesia. Penelitian ini menggunakan regresi logistik untuk analisis data. Hasil penelitian ini menunjukkan bahwa variabel ROA, DER, umur perusahaan dan inflasi berpengaruh terhadap underpricing. Variabel lain tidak pengaruh terhadap tingkat underpricing. Pada model penelitian ini, menunjukkan variable independen bisa menjelaskan variasi tingkat underpricing sebesar $89,6 \%$.
\end{abstract}

Kata kunci: underpricing, faktor internal, faktor eksternal, ROA, DER

\footnotetext{
${ }^{1}$ Corresponding author:

Email: usathoriq@gmail.com
} 


\section{PENDAHULUAN}

Initial Public Offering (IPO) menjadi salah satu pilihan tepat bagi perusahaan privat untuk mendapatkan tambahan dana, terutama untuk ekspansi usaha atau operasi perusahaan bukan hanya bagi perusahaan, bagi investor pasar modal juga menjadi salah satu alternatif untuk menanamkan modalnya (berinvestasi) dengan membeli sejumlah efek dengan harapan akan memperoleh keuntungan yang disebut dengan initial return dari hasil kegiatan tersebut (Larasari et al. 2013). Pasar modal akan membuat semakin banyak perusahaan yang akan go public. Jika semakin banyak perusahaan yang go public, berarti semakin tinggi kualitas yang dihasilkan perusahaan (Bodie et al. 2006).

Tabel 1. Perusahaan yang melakukan Initial Public Offering (IPO) tahun 2010-2015

\begin{tabular}{cc}
\hline Tahun & Jumlah perusahaan IPO \\
\hline 2010 & 23 \\
2011 & 25 \\
2012 & 22 \\
2013 & 29 \\
2014 & 23 \\
2015 & 15 \\
Total & 137 \\
\hline
\end{tabular}

Sumber: www.idx.co.id

Harga saham yang dijual di pasar perdana ditentukan berdasarkan kesepakatan antara perusahaan emiten dan penjamin emisi (underwriter),sedangkan harga di pasar sekunder ditentukan oleh mekanisme pasar (permintaan dan penawaran) (Kristiantari, 2012). Perusahaan yang akan go public menjual sahamnya langsung kepada masyarakat pada saat go public melalui pasar perdana (Sutrisno, 2001). Apabila penentuan harga saham saat IPO lebih rendah dibandingkan dengan harga yang terjadi di pasar sekunder di hari pertama, maka terjadi underpricing. Sebaliknya apabila penentuan harga saham saat IPO secara signifikan lebih tinggi dibandingkan dengan harga yang terjadi di pasar sekunder di hari pertama maka terjadi overpricing.

Menurut Aini (2013) transaksi penawaran umum perdana atau IPO dilakukan oleh emiten (perusahaan go public) untuk pertama kalinya dilaksanakan di pasar perdana (primary market) dengan tujuan agar perusahaan mendapatkan dana sebesar saham yang ditawarkan, kemudian diperjualbelikan di pasar sekunder (secondary market) yang bertujuan menyelenggarakan perdagangan saham yang sudah ada di tangan investor sehingga investor yang ingin menjual atau membeli sejumlah saham terlaksana.

Fenomena underpricing yang terjadi di berbagai pasar modal disebabkan oleh adanya informasi asimetri. Informasi asimetri ini dapat terjadi antara emiten dan penjamin emisi, maupun antar investor. Untuk mengurangi adanya informasi asimetri maka perusahaan yang akan go public menerbitkan prospektus yang berisi berbagai informasi perusahaan yang bersangkutan (Indah, 2006).

Penelitian mengenai underpricing diawali oleh Ibbotson (1975) di pasar modal Amerika Serikat kemudian diikuti oleh para peneliti di berbagai belahan dunia termasuk Indonesia. Dari beberapa penelitian pada setiap pasar efek di seluruh dunia seperti Amerika Serikat (Kim dan Ritter, 1991), Hongkong (Mc Guinnes, 1992), Korea (Kim et al. 1993), serta Australia (How, 1995) menunjukkan bahwa fenomena underpricing terjadi hampir di seluruh Bursa efek. Penelitian dari Witjaksono (2013) menunjukkan bahwa penawaran saham perdana pada perusahaan-perusahaan di Indonesia umumnya mengalami underpricing. Derajat underpricing bervariasi di berbagai pasar modal dunia, mulai yang terendah sebesar $4,3 \%$ di Perancis sampai yang tertinggi di China sebesar $388 \%$. Terjadinya kondisi ini pada umunya disebabkan oleh berbagai faktor baik melalui rasio keuangan ataupun non-keuangan dan variabel makro.

Underpricing terjadi pada 137 perusahaan pada tahun 2010-2015 dimana harga IPO yang ditawarkan pada hari 1 di pasar perdana lebih rendah dari harga penutupan (closing price) saham pada saat hari 1 diperdagangkan di pasar sekunder. Dari 137 perusahaan yang IPO dari tahun 2010-2015 ada sebanyak 115 perusahaan yang mengalami underpricing atau hampir $84 \%$ dari total perusahaan yang melakukan IPO. Dari data tersebut dapat dilihat bahwa kecenderungan perusahaan mengalami underpricing dihari pertama perdagangan saham sangatlah besar. Maka, asumsi bahwa perusahaan akan mengalami underpricing semakin menguat.

Tujuan dalam penelitian, yaitu untuk mengetahui statistik deskriptif dari masing-masing faktor internal terhadap underpricing saat IPO di BEI periode 2010-2015, menganalisis pengaruh faktor internal terhadap underpricing IPO di BEI periode 20102015, menganalisis pengaruh faktor eksternal terhadap underpricing saat IPO di BEI periode 2010-2015. 
Penelitian ini dilakukan untuk menganalisis pengaruh return on asset (ROA), debt to equity ratio (DER), umur perusahaan, ukuran perusahaan, jenis industri, reputasi underwriter, nilai tukar rupiah dan inflasi terhadap underpricing saat penawaran umum saham perdana (IPO). Sampel yang digunakan dalam penelitian ini adalah seluruh perusahaan yang mengalami underpricing saat melakukan penawaran umum saham perdana (IPO) di Bursa Efek Indonesia periode 20102015.

\section{METODE PENELITIAN}

Sampel yang digunakan dalam penelitian ini menggunakan sampel non probabilitas dengan metode purposive sampling. Kriteria perusahaan yang akan menjadi sampel dalam penelitian ini adalah perusahaan yang melakukan IPO di BEI periode 2010-2015, bukan perusahaan relisting pada saat IPO BEI periode 20102015, dan memiliki informasi atau ketersediaan data yang akan digunakan oleh peneliti. Kriteria pemilihan sampel di BEI selengkapanya pada Tabel 2.

Tabel 2. Kriteria pemilihan sampel di Bursa Efek Indonesia

\begin{tabular}{cccccc}
\hline Tahun & IPO & $\begin{array}{c}\text { Over- } \\
\text { pricing }\end{array}$ & $\begin{array}{c}\text { IR } \\
0 \%\end{array}$ & Relisting & $\begin{array}{c}\text { Under- } \\
\text { pricing }\end{array}$ \\
\hline 2010 & 23 & 1 & 0 & 0 & 22 \\
2011 & 25 & 6 & 1 & 0 & 18 \\
2012 & 22 & 1 & 1 & 2 & 18 \\
2013 & 29 & 3 & 3 & 0 & 23 \\
2014 & 23 & 3 & 0 & 0 & 20 \\
2015 & 15 & 1 & 0 & 0 & 14 \\
Total & 137 & 15 & 5 & 2 & 115 \\
\hline
\end{tabular}

Dalam mencapai tujuan digunakan metode regresi logistik (logistic regression) sebenarnya sama dengan analisis regresi berganda, hanya variabel terikatnya merupakan variabel dummy (0 dan 1$)$. Sesuai dengan penelitian ini yang yang menggunakan variable dummy, yaitu nilai 1 untuk underpricing dan nilai 0 untuk overpricing dan initial return $0 \%$.

Interpretasi untuk pengujian model regresi logistic ini dibagi menjadi beberapa poin. Pertama, pengujian secara keseluruhan (overall test). Kedua, pengujian secara parsial (partial test). Bagian terakhir terkait dengan goodness of fit (kelayakan dan kesesuaian model). Sedangkan interpretasi regresi logistik menggunakan odd ratio atau kemungkinan. Regresi logistik akan membentuk variabel prediktor/respon $(\log (\mathrm{p} /(1-\mathrm{p}))$ yang merupakan kombinasi linier dari variabel independen. Nilai variabel prediktor ini kemudian ditransformasikan menjadi probabilitas dengan fungsi logit. Asumsi-asumsi dalam regresi logistik menurut Hosmer dan Lemeshow (2000), yaitu tidak mengasumsikan hubungan linier antar variabel dependen dan independent; variabel dependen harus bersifat dikotomi (2 variabel); variabel independent tidak harus memiliki keragaman yang sama antar kelompok variabel; kategori dalam variabel independent harus terpisah satu sama lain atau bersifat eksklusif; sampel yang diperlukan dalam jumlah relatif besar, minimum dibutuhkan hingga 50 sampel data untuk sebuah variabel prediktor (bebas).

Regresi logistik menghasilkan rasio peluang yang dinyatakan dengan transformasi fungsi logaritma $(\log )$, dengan demikian fungsi transformasi log ataupun $\ln$ diperlukan untuk p-value, dengan demikian dapat dinyatakan bahwa logit(p) merupakan log dari peluang (odds ratio) atau likelihood ratio dengan kemungkinan terbesar nilai peluang adalah 1. Dengan demikian persamaan regresi logistik dimana $p$ bernilai antara $0-1$ menjadi :

$\log (\mathrm{P} / 1-\mathrm{p})=\alpha+\beta_{1} \mathrm{X}_{1}+\beta_{2} \mathrm{X}_{2}+\beta_{3} \mathrm{X}_{3}+\beta_{4} \mathrm{X}_{4}+\beta_{5} \mathrm{X}_{5}+$ $\beta_{6} \mathrm{X}_{6}+\beta_{7} \mathrm{X}_{7}+\mathrm{e}$

Keterangan: $\mathrm{P}$ (Kemungkinan bahwa $\mathrm{Y}=$ 1(Underpricing)); $\alpha$ (Konstanta); $\beta$ (Koefisien Regresi); e (error term); $\mathrm{X}_{1}(\mathrm{ROA}) ; \mathrm{X}_{2}(\mathrm{DER}) ; \mathrm{X}_{3}$ (Age); $\mathrm{X}_{4}$ (Size); $\mathrm{X}_{5}$ (Jenis Industri); $\mathrm{X}_{6}$ (Reputasi Underwriter); $\mathrm{X}_{7}$ (Kurs); $\mathrm{X}_{8}$ (Inflasi).

Sebelum pengujian hipotesis dilakukan, maka terlebih dahulu diperlukan analisis data dan pengujian kelayakan terhadap model regresi logistik yang digunakan sebagai berikut:

\section{Statistik Deskriptif}

Analisis data dengan menggunakan statistik deskriptif terhadap seluruh variabel penelitian berupa nilai ratarata (mean) dan deviasi standard, baik untuk masingmasing tahun maupun selama periode pengamatan (Gozhali,2006). 


\section{Menilai Keseluruhan Model (Overall Model Fit)}

Overall Model Fit adalah pengukuran untuk menentukan keseluruhan model, apakah model yang dihipotesiskan fit dengan data. Beberapa tes statistik digunakan untuk menilai Overall Model Fit yaitu nilai Hosmer and Lemeshow's, Goodness of Fit test, Log Likelihood, Nagelkerke R Square, correlation matrix, dan Classification Table.

Dalam penelitian ini ditentukan bebrapa hipotesis sebafai berikut:

\section{Pengaruh ROA pada Underpricing}

Profitabilitas yang tinggi akan mengurangi ketidakpastian perusahaan di masa yang akan datang dan sekaligus mengurangi ketidakpastian IPO, sehingga akan mengurangi underpricing (Kim et al. 1993). Hal ini juga yang akan berdampak pada harga saham yang akan ditawarkan oleh perusahaan sehingga harga saham akan semakin tinggi. ROA dapat dikatakan baik apabila bernilai $>2 \%$.

H1 : terdapat pengaruha return on asset terhadap underpricing.

\section{Pengaruh DER pada Underpricing}

DER yang tinggi menunjukkan risiko finansial atau risiko kegagalan perusahaan untuk mengembalikan pinjaman akan semakin tinggi, dan sebaliknya. Apabila DER tinggi maka risiko perusahaan akan tinggi pula, sehingga investor dalam melakukan keputusan investasi cenderung menghindari DER yang tinggi karena semakin tinggi DER semakin tinggi pula underpricingnya.

$\mathrm{H} 2$ : terdapat pengaruh dept to equity ratio terhadap underpricing.

\section{Pengaruh AGE pada Underpricing}

Perusahaan yang beroperasi lebih lama mempunyai kemungkinan yang lebih besar untuk menyediakan informasi perusahaan yang lebih banyak dan luas daripada perusahaan yang baru saja berdiri. Dengan demikian akan mengurangi adanya asimetri informasi dan memperkecil ketidakpastian pasar dan pada akhirnya akan memengaruhi underpricing. Berdasarkan hal ini diajukan hipotesis sebagai berikut:
H3 : terdapat pengaruh umur perusahaan terhadap initial return.

\section{Pengaruh SIZE pada Underpricing}

Perusahaan besar umumnya lebih dikenal oleh masyarakat daripada perusahaan kecil. Karena lebih dikenal maka informasi mengenai perusahaan besar lebih banyak dan lebih mudah diperoleh investor dibandingkan perusahaan kecil. Hal ini akan mengurangi asimetri informasi pada perusahaan yang besar sehingga akan mengurangi tingkat underpricing daripada perusahaan kecil karena penyebaran informasi perusahaan kecil belum begitu banyak.

H4 : terdapat pengaruh ukuran perusahaan terhadap underpricing.

\section{Pengaruh JI pada Underpricing}

Risiko untuk setiap jenis industri berbeda karena adanya perbedaan karakteristik. Perbedaan risiko ini menyebabkan tingkat keuntungan yang diharapkan oleh investor untuk setiap sektor industri juga berbeda sehingga tingkat underpricing juga mungkin akan berbeda.

H5 : terdapat pengaruh jenis industri terhadap underpricing.

\section{Pengaruh RU pada Underpricing}

Underwriter dengan reputasi tinggi lebih mempunyai kepercayaan diri terhadap kesuksesan penawaran saham yang diserap oleh pasar. Dengan demikian ada kecenderungan underwriter yang bereputasi tinggi lebih berani memberikan harga yang tinggi sebagai konsekuensi dari kualitas penjaminannya, sehingga tingkat underpricing pun rendah. Reputasi underwriter diyakini menjadi pertimbangan penting bagi investor untuk membeli saham suatu perusahaan.

H6 : terdapat pengaruh reputasi underwriter terhadap underpricing.

\section{Pengaruh KURS pada Underpricing}

Naik turunnya nilai Rupiah terhadap uang asing menyebabkan naik turunnya permintaan saham di pasar modal oleh investor. Artinya, apabila nilai rupiah naik maka permintaan saham di pasar sekunder akan 
meningkat sehingga harga di pasar perdana akan rendah atau terjadi underpricing.

H7 : terdapat pengaruh kurs terhadap underpricing.

\section{Pengaruh IFLASI pada Underpricing}

Inflasi yang tinggi akan menjatuhkan harga saham di pasar, sementara inflasi yang sangat rendah akan berakibat pertumbuhan ekonomi menjadi sangat lamban, dan pada akhirnya harga saham juga bergerak dengan lamban. Di samping itu, inflasi yang tinggi juga bias mengurangi tingkat pendapatan riil yang diperoleh investor dari investasinya. Sebaliknya, jika tingkat suatu negara mengalami penurunan, maka hal ini merupakan sinyal yang positif bagi investor seiring dengan turunnya risiko daya beli uang dan risiko penurunan pendapatan.

H8 : terdapat pengaruh inflasi terhadap underpricing.

Kerangka berpikir dalam penelitian ini diawali dengan menentukan variabel-variabel yang digunakan dalam penelitian ini, yaitu return on asset, debt to equity ratio, umur perusahaan, ukuran perusahaan, jenis industri, reputasi underwriter, nilai tukar rupiah dan inflasi yang memiliki pengaruh tehadap underpricing pada seluruh perusahaan yang melakukan IPO di Bursa Efek Indonesia (BEI) periode 2010-2015. Kerangka pemikiran penelitian selengkapnya pada Gambar 1.

\section{HASIL}

Statistik deskriptif digunakan untuk mengetahui gambaran dari masing-masing variabel yang digunakan dalam penelitian yang dilakukan di Bursa Efek Indonesia. Statistik deskriptif dari masing-masing variabel yang digunakan di Bursa Efek Indonesia pada Tabel 3 .

\section{Uji Validitas dan Reliabilitas}

Dengan mengestimasi parameter regresi logistik menggunakan Maximum Likelihood Estimation (MLE) (Tabel 4) diharapkan dapat meminimumkan jarak antara titik data dan garis regresi. Dari Tabel 5 hasil olah data SPSS pada output Iteration History dapat terlihat bahwa nilai -2 Log Likelihood adalah sebesar 113,261 yang akan dibandingkan dengan nilai $C h i$ Square pada taraf signifikansi 0,05 dengan df sebesar N-1 dengan $\mathrm{N}$ adalah jumlah sampel, berarti $135-1=$ 134. Dari tabel Chi Square, diperoleh nilainya adalah 162.016. Jadi -2 Log Likelihood < Chi Square (113,261 $<$ 162.016) (Tabel 6).

Penurunan -2 Log Likelihood adalah sebesar 113.261$51.177=62.084$. Nilai penurunan -2 Log Likelihood juga dapat dilihat dari output Omnibus Tests of Model Coefficients, yaitu sebesar 62,084 dan mempunyai signifikansi $0,000<0,05$ sehingga menolak H0 yang menunjukkan bahwa penambahan variabel independen dapat memberikan pengaruh nyata terhadap model, atau model dinyatakan fit.

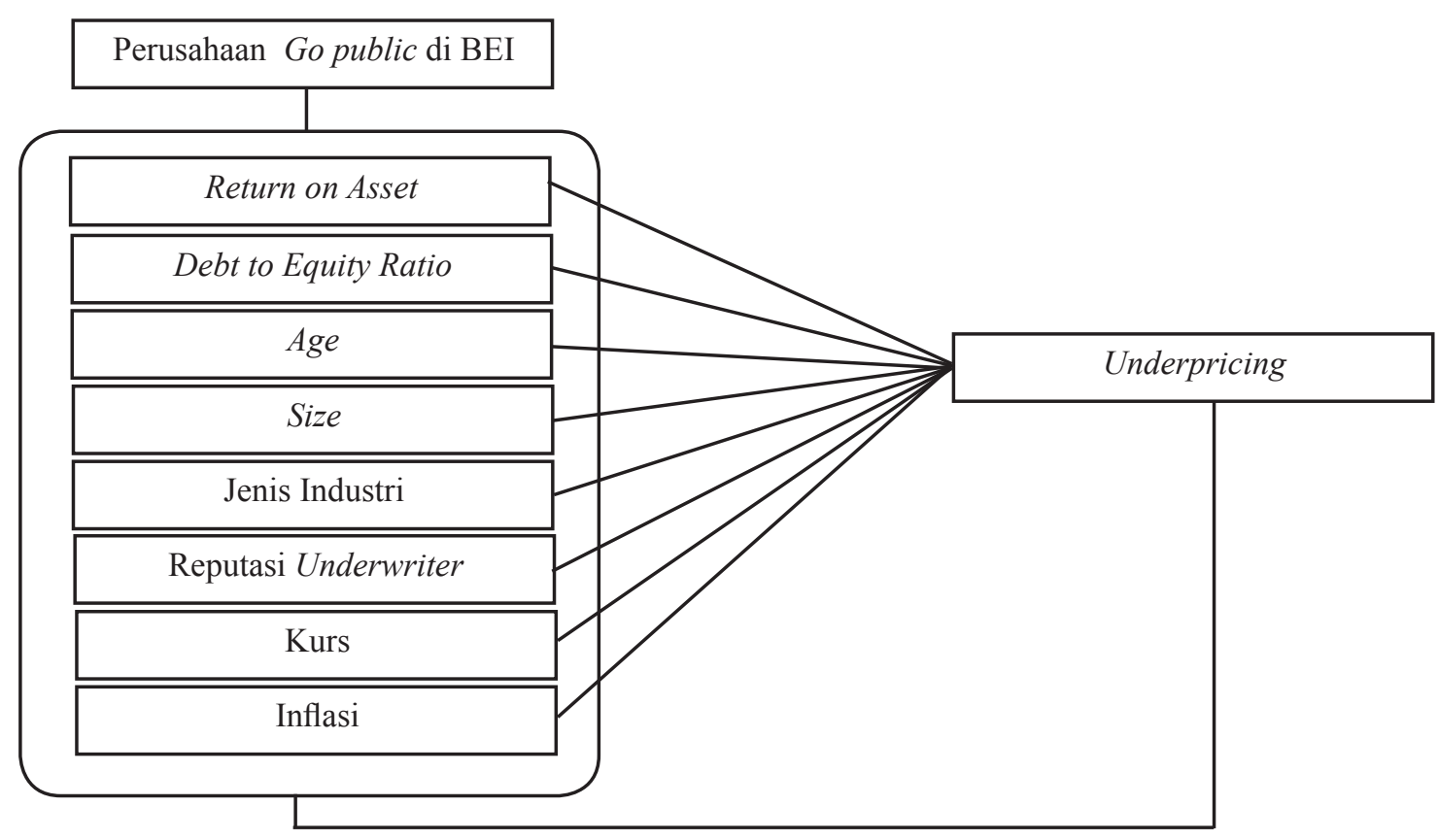

Gambar 1. Kerangka berpikir penelitian 
Tabel 3. Statistik deskriptif

\begin{tabular}{lccc}
\hline Variabel & Minimum & Maximum & Mean \\
\hline Initial Return & $-18,00$ & 70,00 & 20,31 \\
ROA & 0,05 & 68,52 & 5,77 \\
DER & 0,03 & 84,60 & 4,09 \\
AGE & 1 & 90 & 19 \\
SIZE & 22.185 & 32.410 .329 & 3.028 .910 \\
Reputasi & 1 & 106 & 24 \\
Underwriter & & & \\
KURS & 8.521 & 14.065 & 10.310 \\
INFLASI & 2,78 & 8,79 & 5,7701 \\
\hline
\end{tabular}

Tabel 4. Maximum likelihood method

\begin{tabular}{lccc}
\hline \multirow{2}{*}{ Iteration } & $\begin{array}{c}-2 \text { Log } \\
\text { likelihood }\end{array}$ & Coefficients \\
\cline { 3 - 4 } Step 0 & 1 & 115,415 & Constant \\
& 2 & 113,281 & 1,407 \\
& 3 & 113,261 & 1,714 \\
& 4 & 113,261 & 1,749 \\
& & \\
\hline
\end{tabular}

Tabel 5. Variabel in the equation

\begin{tabular}{lccccc}
\hline & $\mathrm{B}$ & $\mathrm{S}, \mathrm{E}$, & Wald & Sig, & $\operatorname{Exp}(\mathrm{B})$ \\
\hline ROA & $-4,80$ & 1,87 & 6,74 & 0,01 & 130,36 \\
DER & 0,69 & 0,34 & 4,06 & 0,04 & 2,01 \\
LOGAGE & $-1,10$ & 0,55 & 4,03 & 0,04 & 0,33 \\
LOGSIZE & 0,02 & 0,33 & 0,00 & 0,93 & 1,02 \\
JI & $-1,12$ & 1,33 & 0,71 & 0,39 & 0,32 \\
RU & 0,01 & 0,01 & 0,95 & 0,32 & 1,01 \\
LOGKURS & 0,35 & 0,59 & 0,35 & 0,55 & 0,70 \\
INFLASI & $-2,30$ & 2,67 & 0,74 & 0,08 & 10,02 \\
Constant & $-11,59$ & 35,57 & 0,10 & 0,74 & 0,00 \\
\hline
\end{tabular}

Tabel 6. Omnibus tests of model coefficients

\begin{tabular}{lllll}
\hline & & Chi-Square & $\mathrm{df}$ & Sig, \\
\hline Step 1 & Step & 62,084 & 8 &, 000 \\
& Block & 62,084 & 8 &, 000 \\
& Model & 62,084 & 8 &, 000 \\
\hline
\end{tabular}

Untuk menguji signifikansi simultan menggunakan nilai Chi-Square dari selisih antara -2 Log likelihood sebelum variabel independen masuk model dan -2 Log likelihood setelah variabel independen masuk model. Ada pengaruh signifikan secara simultan variable independen terhadap underpricing oleh karena nilai $\mathrm{p}$ value Chi-Square sebesar 0,000 di mana $<$ Alpha 0,05 atau nilai Chi-Square Hitung 62,084 > Chi-Square tabel 5,991.
Hosmer dan Lemeshow Test adalah untuk melihat apakah data empiris cocok atau tidak dengan model atau dengan kata lain diharapkan tidak ada perbedaan antara data empiris dengan model. Model akan dinyatakan layak jika signifikansi di atas 0,05 atau-2 Log Likelihood di bawah Chi Square Tabel. Berkebalikan dengan uji yang lain sebelumnya. Nilai Hosmer and Lemeshow Test adalah sebesar 2,065 dengan signifikansi 0,914 (Tabel 7). Nilai Chi Square tabel untuk DF 1 (Jumlah variabel independen - 1) pada taraf signifikansi 0,05 adalah sebesar 3,841. Karena nilai Chi Square Hosmer and Lemeshow hitung 2,065 < Chi Square table 3,841 dan nilai signifikansi sebesar 0,000 $(<0,05)$. Berarti model adalah $f i t$ dan model dinyatakan layak dan boleh diinterpretasikan.

Pada Tabel 8 Model Summary untuk melihat kemampuan variabel independen dalam menjelaskan variabel dependen, digunakan nilai Cox \& Snell R Square dan Nagelkerke R Square. Nilai-nilai tersebut disebut juga dengan Pseudo R-Square atau jika pada regresi linear (OLS) lebih dikenal dengan istilah R-Square. Nilai Nagelkerke R Square sebesar 0,649 yang berarti bahwa delapan variabel independen mampu menjelaskan varians underpricing sebesar $64,9 \% \%$ dan sisanya yaitu sebesar 35,1\% dijelaskan oleh faktor lain. Namun nilai ini hanya sebagai pendekatan saja, karena pada regresi logistik koefisien determinasi tidak dapat dihitung seperti regresi linier. Maka yang perlu diperhatikan adalah seberapa banyak kita dapat memprediksi dengan benar yang tercermin dari nilai classification plot.

Dari Tabel 9 dapat ditunjukan bahwa model regresi logistik yang digunakan telah cukup baik, karena dilihat dari nilai overall percentage mampu menebak dengan benar $89,6 \%$ kondisi yang terjadi. Setelah melakukan uji validitas dan reliabitias dengan menggunakan Maximum Likelihood Estimation (MLE), Omnibus Tests of Model Coefficients dan Hosmer dan Lemeshow Test menunjukan hasil bahwa model fit dan model dinyatakan layak dan boleh untuk diinterpretasikan dan Classification Table menunjukan bahwa model regresi logistik yang digunakan telah cukup baik, karena dilihat dari nialai overall percentage mampu menebak dengan benar $89,6 \%$ kondisi yang terjadi.

Terdapat pengaruh signifikan secara simultan variable independen terhadap underpricing oleh karena nilai $\mathrm{p}$ value Chi-Square sebesar 0,000 di mana $<$ Alpha 0,05 
atau nilai Chi-Square Hitung 62,084 > Chi-Square tabel 5,991.

Dari Tabel 5 hasil model Variabel in the equation regresi logistik maka diperoleh persamaan regresi dalam penelitian ini adalah sebagai berikut:

\section{Underpricing $=-11,59+4,870 \mathrm{ROA}+0,699 \mathrm{DER}-$ 1,11 LOGAGE - 2,30 INFLASI}

Berdasarkan model regresi yang terbentuk pada persamaan tersebut, penjelasan yang dapat diberikan adalah sebagai berikut:

1) Nilai konstanta diperoleh sebesar -11,59. Hasil ini dapat diasumsikan jika tujuhempat variabel bebasnya bernilai nol, maka variabel underpricing mengalami penurunan sebesar 11,59.

2) Koefisien regresi ROA diperoleh sebesar 4,87 menyatakan bahwa setiap penambahan 1\% ROA akan menaikan underpricing sebesar 4,87 dengan catatan variabel lain dianggap konstan.

3) Koefisien regresi DER diperoleh sebesar 0,69 menyatakan bahwa setiap penambahan 1\% DER akan menaikan underpricing sebesar 0,69 dengan catatan variabel lain dianggap konstan.

4) Koefisien regresi LOGAGE diperoleh sebesar $-1,11$ menyatakan bahwa setiap penambahan 1\% LOGAGE akan menurunkan underpricing sebesar 1,11 dengan catatan variabel lain dianggap konstan.

Tabel 7. Hosmer and lemeshow test

\begin{tabular}{cccc}
\hline Step & Chi-Square & df & Sig. \\
\hline 1 & 2,065 & 6 &, 914 \\
\hline
\end{tabular}

Tabel 8. Model summary

\begin{tabular}{cccc}
\hline Step & $\begin{array}{c}-2 \text { Log } \\
\text { likelihood }\end{array}$ & $\begin{array}{c}\text { Cox \& Snell } \\
\text { R Square }\end{array}$ & $\begin{array}{c}\text { Nagelkerke R } \\
\text { Square }\end{array}$ \\
\hline 1 & $51,177 \mathrm{a}$ &, 369 &, 649 \\
\hline
\end{tabular}

Tabel 9. Classification table

\begin{tabular}{|c|c|c|c|c|c|}
\hline & \multirow{3}{*}{ Observed } & & \multicolumn{3}{|c|}{ Predicted } \\
\hline & & & \multicolumn{2}{|c|}{ Underprice } & \multirow{2}{*}{$\begin{array}{c}\text { Percentag } \\
\text { Correct }\end{array}$} \\
\hline & & & 0 & 1 & \\
\hline \multirow[t]{3}{*}{ Step 1} & Underprice & 0 & 13 & 7 & 65,0 \\
\hline & & 1 & 7 & 108 & 93,9 \\
\hline & Overall Per & & & & 89,6 \\
\hline
\end{tabular}

5) Koefisien regresi INFLASI diperoleh sebesar -2.30 menyatakan bahwa setiap penambahan $1 \%$ INFLASI akan menurunkan underpricing sebesar 2,69 dengan catatan variabel lain dianggap konstan.

Dari Tabel 5 dapat diketahui bahwa tidak semua variabel independen yang diteliti berpengaruh signifikan terhadap variabel dependen.

\section{Analisis faktor internal dan eksternal terhadap Underpricing di Bursa Efek Indonesia}

\section{a) Pengaruh ROA terhadap underpricing}

ROA secara parsial berpengaruh signifikan terhadap underpricing. Oleh karena nilai B bernilai positif, maka ROA mempunyai hubungan positif dengan underpricing. Hasil penelitian ini tidak konsisten terhadap penelitian yang dilakukan oleh Wijayanto (2010) yang menyatakan bahwa ROA tidak berpengaruh signifikan dengan arah negatif terhadap underpricing. Namun, hasil penelitian ini konsisten dengan penelitian yang dilakukan oleh Mega dan Viriany (2015) bahwa secara parsial ROA berpengaruh signifikan terhadap underpricing. Menurut Sri (2005), tingkat profitabilitas merupakan informasi tingkat keuntungan yang dicapai atau informasi mengenai efektivitas operasional perusahaan. Semakin tinggi nilai profitabilitas perusahaan menunjukkan semakin tinggi pula laba yang dihasilkannya. Dengan demikian, semakin besar rasio ROA maka semakin tinggi pula harga saham dinilai oleh investor. Jika perusahaan memiliki informasi tentang nilai sekarang dan aliran kas masa depan yang lebih baik daripada investor, underpricing akan menjadi sarana untuk meyakinkan para calon pembeli tentang nilai sebenarnya perusahaan. Variasi dari signaling theory yang diperkenalkan oleh Spence (1973).

Dalam signaling theory, asimetri informasi yang terjadi antara emiten, penjamin emisi, dan antar investor dapat diminimalisir dengan penerbitan prospektus oleh perusahaan (Bini et al. 2011). Variabel keuangan dalam prospektus perusahaan akan memberi signal penting bagi calon investor untuk menanamkan sahamnya di pasar perdana. Profitabilitas merupakan kemampuan emiten untuk menghasilkan keuntungan dan mengukur tingkat efisiensi operasional dan efisiensi dalam menggunakan harta yang dimilikya. Profitabilitas suatu perusahaan yang mencerminkan efektivitas operasional 
perusahaan untuk mendapatkan laba di masa datang. Apabila profitabilitas suatu perusahaan bernilai tinggi maka akan mengurangi risiko ketidakpastian bagi investor. Penggunaan profitabilitas mencerminkan keyakinan manajemen tentang kemampuan perusahaan untuk memperoleh keuntungan yang cukup dimasa datang. Dengan kata lain, peningkatan profitabilitas merupakan signal positif bahwa untuk mendapatkan keuntungan di masa datang lebih tinggi daripada ketidakpastian atau risiko yang dihadapi perusahaan.

\section{b) Pengaruh DER terhadap underpricing}

DER secara parsial berpengaruh signifikan terhadap underpricing. Oleh karena itu, nilai B bernilai positif, maka DER mempunyai hubungan positif dengan underpricing. Hasil penelitian ini tidak konsisten terhadap penelitian yang dilakukan oleh Irawati (2011) dan Gatot et al. (2013) yang menyatakan bahwa DER berpengaruh negatif dan signifikan terhadap underpricing, namun hasil penelitian ini konsisten dengan penelitian yang dilakukan oleh Wahyusari (2013) bahwa secara parsial DER berpengaruh signifikan dengan arah positif terhadap underpricing.

Kewajiban finansial merupakan sumber pendanaan (utang) berbeban bunga yang pada umumnya digunakan untuk membiayai aset tetap/jangka panjang. Kewajiban finansial mencerminkan kepercayaan pasar tehadap peru-sahaan (Susilowati, 2010). Menurut Wahyusari (2013) hal ini terjadi karena secara teoritis DER yang tinggi menggambarkan risiko perusahaan yang besar yang berdampak pada ketidakpastian di masa mendatang. Tingginya DER juga mengurangi minat investor untuk menanamkan sahamnya pada perusahaan. DER yang tinggi menunjukan risiko kegagalan finansial atau kegagalan pembayaran utang terhadap kreditor yang semakin tinggi. Perusahaan dengan nilai DER yang tinggi cenderung menggunakan hasil IPO untuk membayar utang pada kreditur daripada untuk melakukan perluasan usaha dalam rangka mengembangkan perusahaannya. Para investor dalam melakukan keputusan investasi akan mempertimbangkan nilai DER yang tinggi, oleh karenanya tingkat ketidakpastian semakin tinggi sehingga tingkat underpricing cenderung ikut meninggi.
Dari sudut pandang signaling theory, selain sebagai indikator kepercayaan pasar, penggunaan kewajiban finansial mencerminkan keyakinan manajemen tentang kemampuan perusahaan untuk memperoleh aliran kas yang cukup dimasa datang lebih besar dari kewajiban finansialnya. Dengan kata lain, peningkatan kewajiban finansial merupakan signal positif bahwa untuk mendapatkan keuntungan di masa datang lebih tinggi daripada ketidakpastian atau risiko yang dihadapi perusahaan. Oleh karena itu, semakin tinggi financial leverage perusahaan maka semakin besar pula tingkat underpricing.

\section{c) Pengaruh AGE terhadap underpricing}

AGE secara parsial berpengaruh signifikan dengan arah negatif terhadap underpricing. Oleh karena nilai B bernilai positif maka AGE mempunyai hubungan negatif dengan underpricing. Hasil penelitian ini konsisten terhadap penelitian yang dilakukan oleh Yulianti (2011) yang menyatakan bahwa AGE berpengaruh negatif dan signfikan terhadap underpricing, namun hasil penelitian ini tidak konsisten dengan penelitian yang dilakukan oleh Kristiantari (2012) bahwa secara parsial AGE tidak berpengaruh signifikan dan memiliki arah negatif terhadap underpricing.

Semakin lama umur perusahaan, semakin banyak informasi yang telah diperoleh masyarakat tentang perusahaan tersebut. Dengan demikian mengurangi akan adanya asimetri informasi dan memperkecil ketidakpastian dimasa yang akan datang. Hal ini menjelaskan bahwa umur perusahaan yang tinggi (telah lama didirikan) dapat mengurangi tingkat ketidak pastian dan risiko yang dihadapi investor. Investor beranggapan bahwa perusahaan dengan usia yang lebih tinggi telah memiliki pengalaman dan pengetahuan yang lebih baik dalam menjalankan kegiatan usaha dan mengatasi persaingan dengan competitor, serta berpengalaman mengatasi krisis ekonomi yang dapat menyulitkan perusahaan sehingga investor dan underwriter tidak perlu menetapkan harga yang terlalu underpriced agar investor mau terlibat dalam kegiatan penawaran perdana. 


\section{d) Pengaruh SIZE terhadap underpricing}

SIZE secara parsial tidak berpengaruh signifikan dengan arah negatif terhadap underpricing. Hasil penelitian ini tidak konsisten terhadap penelitian yang dilakukan oleh Indah (2006) yang menyatakan bahwa SIZE berpengaruh negatif dan signifikan terhadap underpricing. Namun, hasil penelitian ini konsisten dengan penelitian yang dilakukan oleh Firdaus (2012) bahwa secara parsial SIZE tidak berpengaruh signifikan dengan arah negatif terhadap undepricing.

Secara teoritis perusahaan yang lebih besar mempunyai kepastian (certainty) yang lebih besar daripada perusahaan kecil sehingga akan mengurangi tingkat ketidakpastian mengenai prospek perusahaan ke depan. Hal tersebut dapat membantu investor memprediksi risiko yang mungkin terjadi jika ia berinvestasi pada perusahaan itu (Yolana dan Dwi, 2005). Kinerja perusahaan pada dasarnya merupakan hasil yang dicapai suatu perusahaan dengan mengelola sumber daya yang ada dalam perusahaan dengan seefektif dan seefisien mungkin guna mencapai tujuan yang telah ditetapkan manajemen.

Namun, Scott (2000) tentang asimetri informasi, bahwa fakta yang mungkin dapat memengaruhi keputusan yang akan diambil oleh pemegang saham tersebut seringkali tidak disampaikan informasinya kepada pemegang saham. Seperti dijelaskan pada teori adverse selection, yaitu bahwa para manajer serta orang-orang dalam lainnya biasanya mengetahui lebih banyak tentang keadaan dan prospek perusahaan dibandingkan investor pihak luar, sehingga perusahaan yang besar belum tentu memiliki informasi yang lebih banyak bagi investor. Tidak berpengaruhnya ukuran perusahaan terhadap underpricing disebabkan karena investor lebih menilai kinerja perusahaan yang dianggap lebih penting daripada ukuran perusahaannya. Ukuran perusahaan tidak akan menjadi pertimbangan bagi investor apabila tidak dikelola seefektif dan seefisien mungkin sehingga investor lebih memperhatikan hasil dari kinerja perusahaan tersebut.

\section{e) Pengaruh JI terhadap underpricing}

Variabel jenis industri secara parsial tidak berpengaruh signifikan dengan arah negatif terhadap underpricing. Penelitian ini hanya membedakan perusahaan yang melakukan IPO ke dalam kelompok perusahaan manufaktur dan non manufaktur, sedangkan masih terdapat jenis industri yang memiliki karakteristik khusus seperti industri perbankan. Pengukuran ini digunakan juga oleh Yolana dan Dwi (2005). Jenis industri manufaktur memiliki perbedaan signifikan dengan jenis industri lainnya, yaitu real estate, properti, keuangan, asuransi dan investasi. Perbedaan tersebut antara lain dalam struktur modal dan komponen-komponen neraca dan laba rugi yang dapat memengaruhi perhitungan variabel-variabel keuangan (Gumanti, 2005).

Menurut Kristiantari (2013) risiko untuk setiap jenis industri berbeda karena adanya perbedaan karakteristik. Perbedaan risiko ini menyebabkan tingkat keuntungan yang diharapkan oleh investor untuk setiap sektor industri juga berbeda sehingga tingkat underpricing juga mungkin akan berbeda atau bahkan tidak memengaruhi underpricing.

\section{f) Pengaruh RU terhadap underpricing}

Variabel reputasi underwriter secara parsial tidak berpengaruh signifikan terhadap underpricing. Tidak berpengaruhnya reputasi underwriter terhadap underpricing disebabkan karena penggunaan underwriter yang bereputasi baik oleh emiten tidak memberikan sinyal bagi investor untuk memperkirakan nilai yang pantas (sesungguhnya) bagi perusahaan IPO, hal ini didukung oleh alasan hasil penelitian Aini (2013) bahwa secara parsial reputasi underwritertidak berpengaruh signifikan terhadap underpricing.

Reputasi underwriter memberikan sinyal bagi pasar untuk menilai kualitas emiten yang baik atau buruk. Reputasi underwriter yang baik merupakan sinyal positif bagi investor dalam menilai saham emiten yang berkualitas baik. Namun, terdapat dua syarat sinyal positif yang akan efektif, yakni sinyal tersebut harus sampai ke calon investor dan dipersepsikan baik serta tidak mudah ditiru oleh perusahaan yang berkualitas rendah. Sebaliknya, penggunaan underwriter yang bereputasi baik relatif mudah ditiru oleh semua emiten, sehingga investor tidak dapat membedakan kualitas emiten yang baik dan yang buruk dengan hanya melihat underwriter yang melakukan penjaminan emisi pada saham IPO (Aini, 2013).

Sesuai dengan penjelasanpada model Rock (Rosyati dan Sebeni, 2002) diasumsikan bahwa fenomena 
underpricing terjadi karena informasi asimetris pada kelompok investor yang memiliki informasi tentang prospek perusahaan emiten tanpa melibatkan pihak underwriter.

\section{g) Pengaruh KURS terhadap underpricing}

Variabel nilai tukar rupiah secara parsial tidak berpengaruh signifikan dengan arah negatif terhadap underpricing. Perubahan faktor ekonomi makro tidak akan dengan seketika memengaruhi kinerja perusahaan, tetapi secara perlahan dalam jangka panjang (Samsul, 2006). Investor tidak memperhatikan rata-rata kurs dalam menentukan berinvestasi atau menentukan harga. Hal tersebut mungkin dikarenakan kondisi perekonomian Indonesia yang tidak stabil. Kurs rupiah terhadap dolar naik turun dan sangat sulit untuk diprediksikan. Oleh karena itu, apabila investor sangat memperhatikan perubahan kurs dapat menimbulkan kesalahan dalam memprediksi harga saham maupun prospek perusahaan ke depan.

Menurut Jufri (2013) hal ini dikarenakan para investor tidak terlalu dalam menganalisis informasitentang kurs dimana informasi ini berasal dari luar perusahaan atau eksternal, dengan mungkin juga perbandingan perubahan rata-rata kurs yang terjadi antarbulan tidak terlalu besar sehingga investor menganggap bahwa kurs tidak berpengaruh dalam pengambilan keputusan dalam pembelian saham, dan kegiatan IPO ini sendiri adalah langkah awal yang dilakukan sebuah perusahaan sebelum saham emiten diperjualbelikan secara bebas di BEI.

\section{h) Pengaruh INFLASI terhadap underpricing}

INFLASI secara parsial berpengaruh signifikan terhadap underpricing. Oleh karena nilai B bernilai negatif, maka inflasi mempunyai hubungan negatif dengan underpricing. Hasil penelitian ini mendukung penelitian yang telah dilakukan oleh Lestari (2005) bahwa inflasi berpengaruh signifikan terhadap underpricing. Namun, tidak konsisten dengan penelitian oleh Aprilianti (2008), yang menunjukkan bahwa tidak ada pengaruh signifikan tingkat inflasi terhadap underpricing saham perusahaan IPO.

Inflasi merupakan salah satu indikasi tentang adanya ketidakstabilan perekonomian di Indonesia. Inflasi merupakan proses kenaikan harga secara terus- menerus yang berlaku dalam suatu perekonomian dan terjadi penurunan nilai uang (Lestari, 2005). Dalam teori efisiensi pasar bahwa informasi didasarkan pada ketersediaan informasi harga atau nilai dari sekuritas mencerminkan semua informasi dan informasi tersebut dapat diperoleh secara terbuka dan cepat tanpa ada hambatan yang khusus. Kenaikan laju inflasi akan meningkatkan harga barang dan jasa, yang akan meningkatkan biaya modal perusahaan sehingga akan berpengaruh terhadap harga saham. Ketika inflasi tinggi, harga barang akan naik, sehingga biaya yang dikeluarkan perusahaan juga akan besar dan itu berdampak pada laba yang diperoleh perusahaan. Dengan begitu, emiten akan cenderung menekan harga saham ketika IPO. Demikian dengan investor, sebagian besar masyarakat akan mengurangi kegiatan investasinya karena faktor kenaikan harga barang konsumsi.

Kenaikan laju inflasi yang tidak terantisipasi akan meningkatkan harga barang dan jasa sehingga konsumsi akan menurun, selain itu kenaikan harga faktor produksi juga akan meningkatkan biaya modal perusahaan sehingga laju inflasi yang tidak terkendali akan menurunkan nilai dari perusahaan termasuk laba perusahaan. Turunnya laba perusahaan akan menurunkan minat investor untuk membeli saham pada saat IPO. Oleh karena itu, kenaikan inflasi akan menurunkan harga saham sehingga berpengaruh terhadap tingginya underpricing (Samsul, 2006). Jadi, secara teori tingginya inflasi akan menurunkan tingkat underpricing saham perusahaan yang melakukan penawaran saham perdana.

\section{Implikasi Manajerial}

Hasil analisis yang dilakukan terhadap variable yang memengaruhi underpricing maka dapat dirumuskan beberapa implikasi manajerial yang dapat dilakukan oleh investor dan juga emiten untuk terus melakukan investasi.

\section{Bagi Investor}

Penelitian ini diharapkan dapat menjadi bahan pertimbangan untuk menginvestasikan dana di pasar modal dan agar diperoleh return secara optimal bagi investor. Investor dapat mempertimbangkan faktor fundamental perusahaan terhadap underpricing. 
Variabel keuangan dalam prospektus perusahaan akan memberi sinyal penting bagi investor untuk menanamkan sahamnya di pasar perdana.

Peningkatan profitabilitas merupakan sinyal positif untuk investor bahwa untuk mendapatkan keuntungan di masa datang lebih tinggi daripada ketidakpastian atau risiko yang dihadapi perusahaan. DER dapat menjadi sinyal positif bagi investor, apabila dalam prospektus yang telah diterbitkan oleh perusahaan menjelaskan bahwa hutang perusahaan digunakan untuk ekspansi perusahaan. Maka investor yakin perusahaan tersebut memiliki prospek yang bagus dimasa mendatang. Investor beranggapan bahwa perusahaan dengan usia yang lebih tinggi telah memiliki pengalaman dan pengetahuan yang lebih baik dalam menjalankan kegiatan usaha dan mengatasi persaingan dengan competitor, serta berpengalaman mengatasi krisis ekonomi yang dapat menyulitkan perusahaan sehingga investor mau terlibat dalam kegiatan penawaran perdana. Karena pada dasarkan investor lebih memperhatikan hasil dari kinerja perusahaan tersebut dibandingkan dengan ukuran perusahaan. Penggunaan underwriter yang bereputasi baik relatif mudah ditiru oleh semua emiten sehingga investor tidak dapat membedakan kualitas emiten yang baik dan yang buruk dengan hanya melihat underwriter yang melakukan penjaminan emisi pada saham IPO. Perubahan kurs dapat menimbulkan kesalahan dalam memprediksi harga saham maupun prospek perusahaan ke depan. Investor juga harus berhati-hati dalam berinvestasi di Indonesai, inflasi merupakan salah satu indikasi tentang adanya ketidakstabilan perekonomian di Indonesia. Karena secara teori tingginya inflasi akan menurunkan underpricing saham perusahaan yang melakukan penawaran saham perdana.

\section{Emiten}

Penelitian ini diharapkan dapat bermanfaat bagi emiten untuk memengaruhi investor dalam mengambil keputusan investasi. Jika perusahaan memiliki informasi tentang nilai sekarang dan aliran kas masa depan yang lebih baik daripada investor, underpricing akan menjadi sarana untuk meyakinkan para calon pembeli tentang nilai sebenarnya perusahaan. Penerbitan prospektus yang jelas memiliki peranan penting dalam pengambilan keputusan tersebut.
Karena perusahaan tahu dengan kinerja perusahaan yang baik maka perusahaan dapat menetapkan harga pembukaan dengan baik sehingga investor tidak akan ragu untuk menginvestasikan dana mereka. Emiten harus bisa menjelaskan bagaimana pengelolaan hutang perusahaan tersebut dimasa yang akan dalam dalam prospektus yang mereka terbitkan. Perusahaan yang telah lama berdiri memiliki keunggulan dalam hal publikasi perusahaan dibandingkan dengan perusahaan yang masih baru karena lebih dahulu dikenal oleh investor. Perusahaan yang besar secara teoritis mempunyai tingkat kepastian (certainty) yang lebih besar daripada perusahaan kecil sehingga akan mengurangi tingkat ketidakpastian mengenai prospek perusahaan ke depan. Underpricing terjadi pada setiap jenis industri. Oleh karena itu, emiten harus berhati-hati ketika menerbitkan saham. Karena penilaian investor untuk setiap jenis industri berbedabeda. Emiten sebaiknya memilih underwriter yang full commitment terhadap saham mereka untuk berjaga-jaga apabila harga saham turun dan kecilnya minat investor terhadap saham mereka. Perubahan suatu variabel makro ekonomi memiliki dampak yang berbeda-beda terhadap setiap jenis saham.

\section{KESIMPULAN DAN SARAN}

\section{Kesimpulan}

Nilai -2 Log Likelihood < Chi Square $(113,261<$ 162.016). Dilihat dari output Omnibus Tests of Model Coefficients, yaitu sebesar 62,084 dan mempunyai signifikansi 0,000<0,05. Selnjutnya, nilai Chi Square Hosmer and Lemeshow hitung 2,065 < Chi Square table 3,841 dan nilai signifikansi sebesar $0,000(<0,05)$. Berarti model adalah fit dan model dinyatakan layak dan boleh diinterpretasikan. Model regresi logistik yang digunakan telah cukup baik, karena dilihat dari nialai overall percentage mampu menebak dengan benar $89,6 \%$ kondisi yang terjadi.

Faktor internal yang berpengaruh signifikan terhadap underpricing saat IPO di Bursa Efek Indonesia periode 2010-2015 adalah ROA, DER dan umur perusahaan. Variabel ROA memiliki nilai signifikansi $0,01<0,05$ dan nilai $\mathrm{B}$ bernilai negatif, maka ROA mempunyai hubungan negatif dengan underpricing. Variabel DER memiliki nilai signifikansi $0,04<0,05$ dan nilai $\mathrm{B}$ bernilai positif maka DER mempunyai hubungan 
positif dengan underpricing. Variabel umur memiliki nilai signifikansi $0,04<0,05$ dan nilai $\mathrm{B}$ bernilai positif, maka umur mempunyai hubungan positif dengan underpricing.

Faktor eksternal yang berpengaruh signifikan terhadap underpricing saat IPO di Bursa Efek Indonesia periode 2010-2015 adalah inflasi yang merupakah variable makro. Variabel nilai inflasi memiliki nilai signifikansi 0,08 . Dengan menggunakan tingkat Alpha $10 \%(0.10)$, $0.08<0,10$ dan nilai $\mathrm{B}$ bernilai positif maka inflasi mempunyai hubungan positif dengan underpricing

\section{Saran}

Saran untuk penelitian mendatang, yaitu peneltian yang akan datang dapat menguji variabel-variabel lain yang juga berpengaruh terhadap underpricing, misalnya variabel quick ratio, karena quick ratio adalah variable keuangan yang paling liquid dibandingkan dengan vatiabel keuangan lainnya. Dan jenis industri yang digunakan dapat lebih bervariasi, misalnya dengan membedakan antara perusahaan tambang dan nontambang, dikarenakan resiko saham yang terdapat dalam perusahaan tambang lebih besar dibandingkan perusahaan jenis lainnya. Faktor ekonomi makro yang digunakan dalam penelitian ini adalah kurs dan inflasi, terdapat juga pengaruh jumlah uang beredar yang dapat digunakan sebagai faktor yang memengaruhi underpricing, untuk dapat mengukur bagaimana investor memanfaatkan dana yang mereka miliki untuk berinvestasi.

Penelitian ini menggunakan sampel perusahaan yang terdaftar di Bursa Efek Indonesia. Untuk penelitian selanjutnya diharapkan dapat melakukan pengujian pada semua perusahaan yang terdaftar di Bursa Efek Indonesia dan Daftar Efek Syariah agar sample yang diteliti dapat lebih beragam.

\section{DAFTAR PUSTAKA}

Aini SH. 2013. Faktor yang memengaruhi underpricing saham pada perushaan IPO di BEI periode 20072011. Jurnal Ilmiah Manajemen 1(1): 88-102.

Aprilianti D. 2008. Pengaruh current ratio, suku bunga bank dan inflasi terhadap underpricing pada penawaran saham perdana di Bursa Efek Jakarta [tesis]. Jakarta: Fakultas Ekonomi Universitas Islam Indonesia.
Bini L, Francesco D, Francesco G. 2011. Signalling Theory and Voluntary Disclosure to The Financial Market (Evidence from the Profitability Indicators Published in the Annual Report). Paper presented at the 34th EAA Annual Congress 34(1): 20-22.

Bodie Z, Kane A, Markus AJ. 2006. Investments. Ed ke-1. Zulaini D, Budi W. Penerjemah. Jakarta: Salemba Empat.

Firdaus MD. 2012. Analisis faktor-faktor yang memengaruhi terjadinya underpricing pada IPO syariah [tesis]. Jakarta: FEB UIN Jakarta.

Gatot NA, Isti I, Agung DB. 2013. Pengaruh DER, ROI, current ratio dan rata-Rata kurs terhadap undepricing pada initial public offering. Jurnal Riset Manajemen Sains Indonesia 4(2): 20-39.

Ghozali I. 2006. Aplikasi Analisis Multivariate dengan Program SPSS. Semarang: Universitas Diponegoro.

Gumanti TA. 2002. Underpricing dan biaya-biaya di sekitar initial public offering. Wahana 5(2): 4768.

Hosmer DW, Lemeshow S. 2000. Applied Logistic Regression. New York: John Wiley and Sons. https://doi.org/10.1002/0471722146.

How, Jay R, Ivo W. 1995. A review of IPO activity, pricing, and allocations. Journal of Finance 57(13): 1795-1828.

Ibbotson. 1975. Price performance of common stock new issuses. Journal of Financial Economics 1(1): 165-184.

Indah RS. 2006. Analisis pengaruh informasi keuangan dan non keuangan terhadap initial return dan return 7 Hari Setelah IPO di Bursa Efek Jakarta [tesis]. Semarang: Universitas Diponegoro.

Irawati SU. 2011. Analisis pengaruh informasi akuntansi dan non akuntansi terhadap initial return pada perusahaan yang melakukan initial public offering di bursa efek indonesia. Jurnal Akuntansi, Fakultas Ekonomi, Universitas Gunadarma 8(2): 56-80.

Jufri Y. 2013. Fenomena underpricing saham yang dipengaruhi faktor internal dan eksternal (studi pada perusahaan yang go public yang terdaftar di BEI Tahun 2007-2010 [tesis]. Lampung: Universitas Lampung.

Kim JB, Itzhak K, Lee J. 1993. Motives for going public and underpricing: new findings from Korea. Journal of Business Financial and Accounting 2(8): 195-211. https://doi.org/10.1111/j.14685957.1993.tb00659.x. 
Kim M, Ritter. 1991. Valuing IPOs. Journal of Financial Economics 5(3): 13-35.

Kristiantari IDA. 2013.Analisis faktor-faktor yang memengaruhi underpricing saham pada penawaran saham perdana di Bursa Efek Indonesia. Jurnal Ilmiah Akuntansi dan Humanika 2(2): 785-811.

Larasati D, Irwanto AK, Permanasari Y. 2013. Analisis strategi optimalisasi portofolio saham LQ 45 (pada Bursa Efek Indonesia Tahun 2009-2011). Jurnal Manajemen dan Organisasi 4(2): 164 171

Lestari M. 2005. Pengaruh variabel makro terhadap return saham di Bursa Efek Jakarta: pendekatan beberapa model. Jurnal dan Prosiding SNA Simposium Nasional Akuntansi 8(1): 258-269.

Mc Guiness P. 1992. An Eximination of the underpricing of intial public offering in Hongkong. Journal of Business Finance and Accounntting 1(1): 165184. https://doi.org/10.1111/j.1468-5957.1992. tb00617.x.

Mega G, Viriany J. 2015. Faktor-faktor yang memengaruhi tingkat underpricing saham pada perusahaan yang melakukan IPO di BEJ. Jurnal
Ekonomi 10(2): 20-35.

Rosyati, Sebeni A. 2002. Analisis faktor-faktor yang memengaruhi underpricing saham pada perusahaan go public di bursa efek jakarta (Tahun 1997-2000). Simposium Nasional Akuntans 5(5): 286-297.

Samsul M. 2006. Pasar Modal dan Manajemen Portofolio. Surabaya: Penerbit Erlangga.

Scott WR. 2000. Financial Accounting Theori. Ed ke-2. Canada: Prentice Hall Canada Inc.

Spence, Michael. 1973. Job market signaling. The Quarterly Journal of Economics 87(3): 355-34. https://doi.org/10.2307/1882010.

Sri T. 2005. Analisis faktor-faktor yang memengaruhi tingkat underprecing pada perusahaan yang go public di Bursa Efek Jakarta. Jurnal Akuntansi dan Keuangan 4(2):149-152.

Susilowati Y. 2010. Konsekuensi signal prospectus perusahaan terhadap initial return saham pada pasar perdana di BEI. Dinamika Keuangan dan Perbankan 2(1): 23-37.

Sutrisno. 2001. Manajemen Keuangan (Teori, Konsep, Aplikasi). Yogyakarta: Ekonisia. 